\title{
Virtual Rebuilding and Documentation of the Historical Old Market of Domat Al-Jandal City
}

\author{
Majed Alzara
}

Department of Civil Engineering, Jouf University, Saudi Arabia

Received January 14, 2021; Revised March 2, 2021; Accepted March 23, 2021

\section{Cite This Paper in the following Citation Styles}

(a): [1] Majed Alzara , "Virtual Rebuilding and Documentation of the Historical Old Market of Domat Al-Jandal City," Civil Engineering and Architecture, Vol. 9, No. 2, pp. 512-522, 2021. DOI: 10.13189/cea.2021.090223.

(b): Majed Alzara (2021). Virtual Rebuilding and Documentation of the Historical Old Market of Domat Al-Jandal City. Civil Engineering and Architecture, 9(2), 512-522. DOI: 10.13189/cea.2021.090223.

Copyright $\bigcirc 2021$ by authors, all rights reserved. Authors agree that this article remains permanently open access under the terms of the Creative Commons Attribution License 4.0 International License

\begin{abstract}
Urban heritage is a precious asset for humanity, reflecting its accomplishments over the eras. There are many buildings and heritage sites that have been lost due to lack of interest in documenting and preserving them. At this present time, when the information about these buildings and heritage sites are available, that leads to make studies for virtually rebuilding them. The aim of this study is to use modern technology to virtually rebuild and document the data of the old market of Domat Al-Jandal, and make a virtual rebuilding of the market, to be a strong historical addition to this archaeological area as it was before. This historical market was one of the most famous old markets in the Arabian Peninsula, which was destroyed in 1974 as a result of urban development and the absence of development strategies to protect the market's urban heritage. The author digitally documents and preserves the market for architectural, urban, construction, and other purposes. The study includes a set of important steps, beginning with collecting information from different sources about the old market through interviews and collecting both of old and new aerial photographs for the case study site. Computing software and 3-D digital modeling technology are then used to virtual rebuilding of the market and document it via a virtual reality system using real materials. Finally, this study provides details related to the features and terrain of the ancient Dumat Al-Jandal market. The study showed that the reconstructed market will consist of two parts with 42 shops, 33 shops facing on the corridor of market s piazza, and 9 of which were with piazza-facing entrances.
\end{abstract}

Keywords Urban Heritage, Dumat Al-Jandal Ancient Market, New Technologies, Architecture, Urban Design

\section{Introduction}

The city of Dumat Al-Jandal was selected as this project's study area. It is one of the significant cities that have a rich cultural heritage. Moreover, it is the best-known oasis at the northern limit of the great Al-Nafud desert, located in the region of Al-Jouf, north of Saudi Arabia (Figure 1). According to Charloux and Loreto [4], Dumat Al-Jandal was considered an important location for ancient trade routes connecting the Arabian Peninsula with cultures to the north.

The city of Dumat Al-Jandal is characterized by the existence of many old buildings and historical sites from different periods such as Mârid Castle, The Mosque of 'Umar bin al-Khattab, Aldara Quarter, and The Historic Old Market of Dumat Al-Jandal.

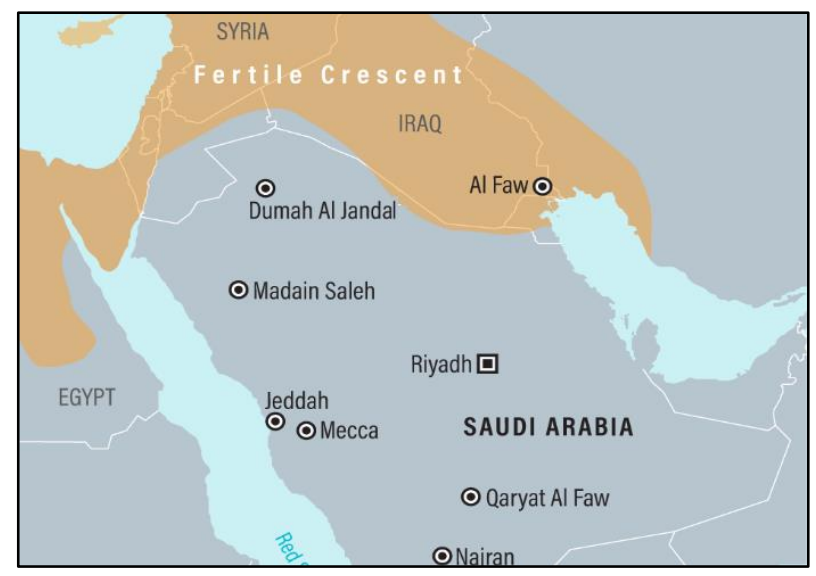

Figure 1. (Map of Saudi Arabia), Location of Dumat Al-Jandal City ${ }^{4}$

Mârid Castle (Figure 2) which is considered as the most 
important historical buildings in Dumat Al-Jandal, dating back to before the eighth century CE [4]. It stands on a natural limestone outcrop, overlooking the valley where the ancient oasis lies,

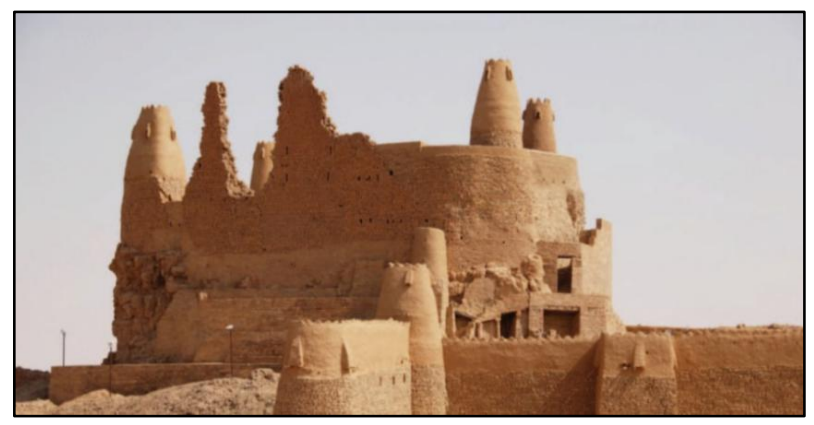

Figure 2. Mârid Castle
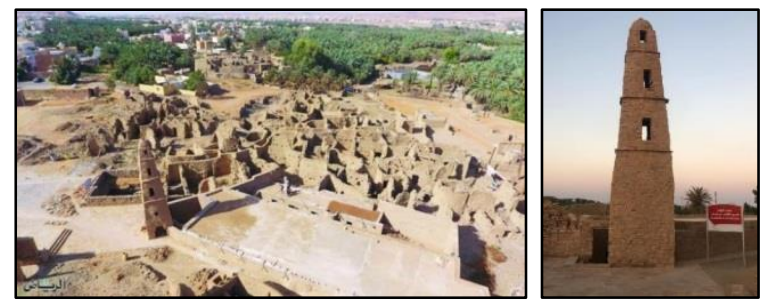

Figure 3. 'Umar bin al-Khattâb Mosque
The Mosque of 'Umar bin al-Khattab (Figure 3), according to Al-Jasser [1] this mosque has been constructed in the Umayyad period (661-749 CE), although some other researchers contend that it has been built during the reign of the second caliph Umar ibn al-Khattab (634-644 CE), with whom it shares its name.

Aldara Quarter, it is located in the neighborhood of 'Umar bin al-Khattâb Mosque and Mârid castle and is considered one of the remaining antiquities of Dumat Al Jandal's ancient city that escaped the demolition befalling the historical market of Dumat Al Jandal forty-six years ago.

The Historic Old Market of Dumat Al-Jandal, which was considered as one of the most famous old markets (Souqs) in the Arabian Peninsula, The ancient Arab markets (Souqs) were periodically established in different parts of the Arabian Peninsula and served not only for trade but also for literary gatherings. The most famous Souqs were: Al Mashqar's Market, Habasha's Market, Sahar Market, Dubai Market, Dhi Al Majaz's Market, Natat Khaybar Market, Okaz Market, Al Majnah Market, Hijr Market, Oman Market, Hadr MMauth Market, Alshohr Market, Sanaa Market, Adan Market, and Dumat Aljandal Market, as shown in Figure (4). [2]

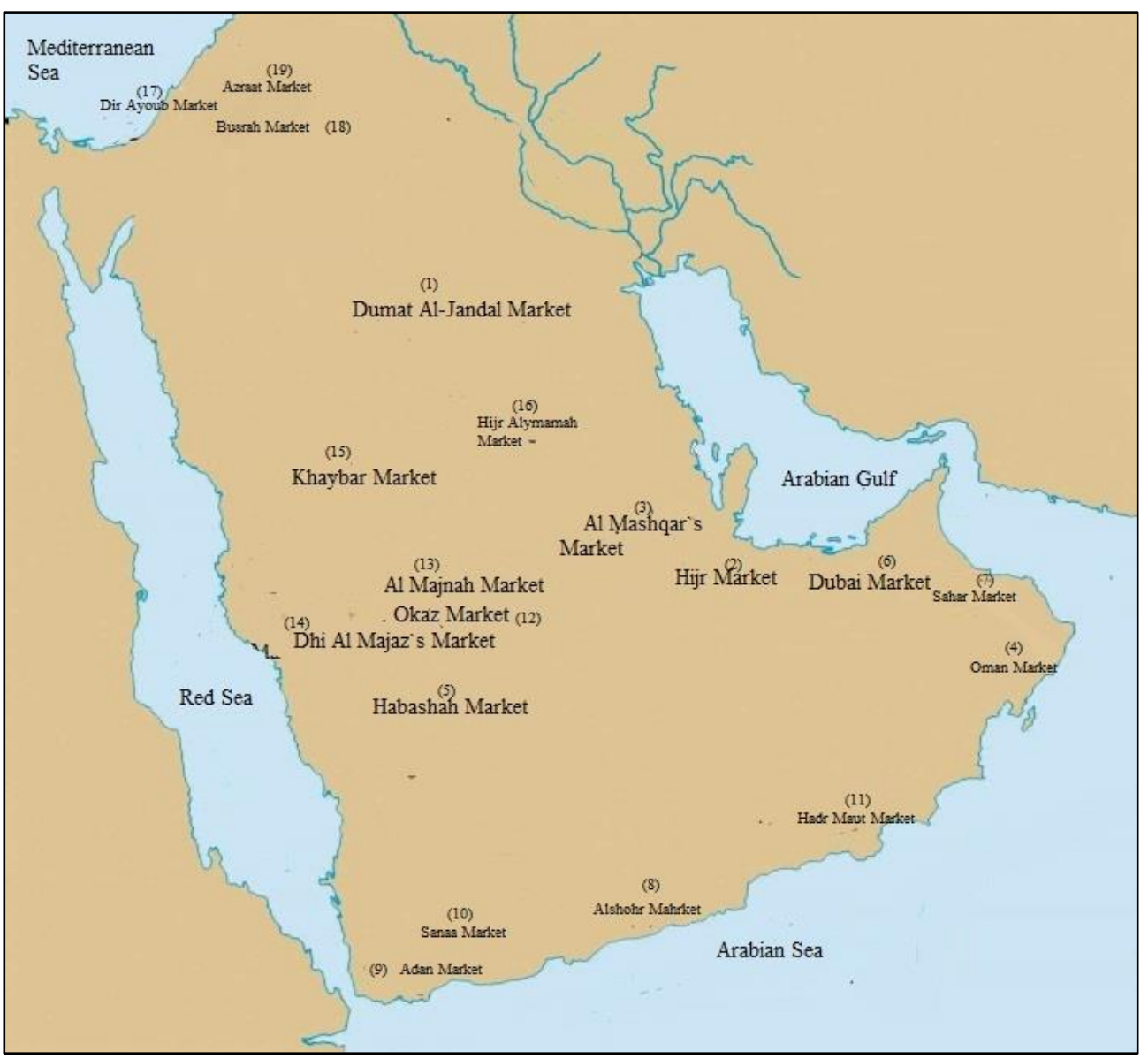

Figure 4. The old Ancient Arab markets in the Arabian Peninsula [2]. 
This research study will focus on the historical market of Domat Al-Jandal, According to Ghabban and Weber [5], this market attracted merchants from all over northern Arabia. Many Arab tribes traded in this market from the first day of Rabiu-alawwal, the third month of the lunar calendar, and remained there for a fortnight each year. Figure (5) shows an image of the western part of the Dumat Al-Jandal oasis taken in 1914 by the British Captain Shakespear [4]. In the foreground, to the right, are the residential neighborhood and the mosque of 'Umar. In the foreground to the left is a large brick construction with a tower that could be the town market. At the back on the left are one or perhaps two towers standing on the plateau and overlooking the palm grove, just next to the promontory known as al-Burj.

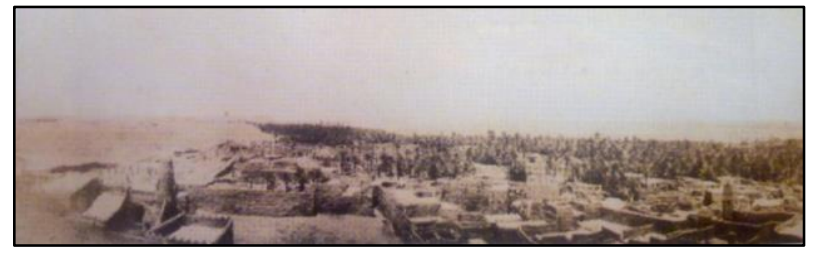

Figure 5. Photograph of the western part of the oasis taken in 1914 by the British Captain Shakespear [4]

\section{Problem}

The Dumat Al-Jandal market has been considered as the most important ancient market in the northern Arabian Peninsula. However, this market was completely destroyed in 1974 through faulty decision-making during that period's urban development and through the absence of development strategies to protect the market's urban heritage. Fortunately, none of the monuments surrounding the market were affected and have been maintained, including the famous Mârid Castle, the mosque of 'Umar Ibn al-Khattâb, and the Aldara archaeological quarter. However, no studies have been conducted to document and rebuild the Dumat Al-Jandal market.

\section{Research Questions}

1. Where was the location of the ancient Dumat Al-Jandal market in relation to the surrounding heritage area?

2. What was the general perception of the Dumat Al-Jandal market?

3. What were the market's dimensions?

4. What building materials were used in the market?

5. What was the Dumat Al-Jandal market's architectural style?

\section{Objectives of the Study}

The objectives of this study are as follows:
1. Determining the damages in the historical area of the market.

2. Making a virtual rebuilding of the market to include the rebuilding of corridors and storefronts while maintaining and preserving the site's authenticity and heritage and the surrounding environment.

3. Documenting the market site to help those interested in urban heritage, and to provide a service to the Tourism and Municipalities Authority to use this research for constructing the market and enhance the urban heritage of Domat Al-Jandal.

\section{Literature Review}

\subsection{Cultural Heritage}

Cultural heritage is the legacy of physical artifacts and intangible attributes of a group or society that are inherited from past generations, maintained in the present, and preserved for the benefit of future generations.

The cultural heritage includes both tangible culture (buildings, monuments, landscapes, books, artworks, antiques) and intangible cultural traditions (oral traditions, performing arts, and knowledge and practices related to nature). Whatever the shape of cultural heritage, it requires an active effort to be protected.

Knowing the concepts of urban design and linking them to the urban heritage of the historical cities lead to evoke these cities` heritage to become clear and livable. Miodrag et al., [6] have made relations between relevant theories resulting in principles of tracing relation between two models taking into account Landry's concept of Creative city, and Castells's theory of Project identity.

According to Yaman [7], Architecture can reflect the lifestyle and culture of a community. People may live in a certain society and by realizing the traditional architecture of this region, they can be able to make smart use of the surrounding environment materials.

The conservation and preservation of important cultural heritage assets have become a concern of the interdisciplinary scientific community. Six sites in Saudi Arabia are included in the UNESCO World Heritage List: Madâin Sâlih, At-Turaif District in ad-Diriyah, Historic Jeddah, the Gate to Makkah, rock art in the Hail region of Saudi Arabia and, the most recent to be added to the list in June 2018, the Al-Ahsa oasis [8].

\subsection{Digital Preservation of Cultural Heritage}

Horošavin [9] stated that cultural heritage practice has taken significant steps toward the use of new digital technologies, now used in many cultural preservation projects. This technology is not only used to preserve existing architecture and heritage but also makes it possible to restore heritage that has been damaged or 
destroyed in some way as long as it has been properly documented. Currently, software packages are available that provide opportunities for manual, semi-automatic, and even automatic 3-D image-based model generation. However, semi-automatic or even manual methods are still used, especially for complex structures where high accuracy on details is essential. For example, Antonios and Loumos [3] presented two distinct approaches for 3-D reconstruction of the historical city of Nafplio (in Greece) by developing 3-D models for buildings and monuments as they were in the 19th century.

According to Yastikli [10], much recent research has focused on using laser scanning technology for 3-D modeling of cultural heritage objects with high accuracy within a short time frame. However, a clear advantage of image-based modeling over laser scanning is the low cost of the equipment, one reason why this method is preferable when budget limitations are present. However, because of the limited field of view (FOV) available when using standard images and videos and aiming for maximum object coverage, researchers started to investigate the use of spherical stereo images [7]. In general, metric applications with high-resolution rotating cameras were a focus for many researchers in the field [8].

Koeva [12] compared the various techniques for the creation and interactive web-based visualization of 3-D models in terms of their visual and metric qualities. Techniques include (1) image-based modeling using a nonmetric handheld camera, (2) 3-D visualization based on spherical panoramic images, and (3) 3-D geometric and photorealistic modeling based on architectural CAD drawings. These comparisons demonstrated that image-based modeling and panoramic visualization are simple, fast, and effective techniques suitable for simultaneous virtual representation of many objects; however, CAD data are beneficial for obtaining higher accuracy and additional measurements.

\section{Methodology}

The data were collected on the market from literature reviews that referenced it and on reviewing methods used to document destroyed architecture and heritage. Also the data were collected from older residents of Dumat al-Jindal who had lived and worked near the market before it was destroyed. The conversations were conducted with them and gave an insight into the history of the site and the historical importance of the market. Through this approach, this allowed to determine the nature and shape of the market's shops and corridors. Then both of old and new aerial photographs for the case study site were collected. In addition to a contour map which depicted the market's surrounding area in three dimensions. The second part of the study was based on using of computing programs and digital 3-D modelling technology to preserve and document the market via the virtual reality system with real materials. Finally, this study provide a detailed depiction of plans, elevations, shapes, corridors, and 3-D perspectives of the Dumat Al-Jandal ancient market to assist in its documentation and encourage its reconstruction.

\section{The Dumat Al-Jandal Ancient Market Case Study}

The main purpose of this research is to reconstruct the destroyed historical market of Dumat al-Jandal. A series of important steps and actual studies have resulted in a viable and realistic concept for locating the market, reconstructing it, and linking it with the surrounding monuments. The case study was conducted in four steps described in the following subsections.

\subsection{Data Collection}

Data collection, a critical process for accurately identifying the required information and its sources, was reliant in this study on two important methods. The first involved communication with the older residents of Dumat al-Jindal who had knowledge of the market before it was destroyed; interviews with them helped identify the market's location. The market consisted of two store-lined sides of an alley connecting the ancient neighborhood with 'Umar bin al-Khattâb Mosque. This alley ended with a large piazza with more stores that also formed part of the market. In addition, the market was built of rough stones common to Dumat Al-Jandal; shop doors were made of native tamarisk and palms, which are widespread throughout the city.

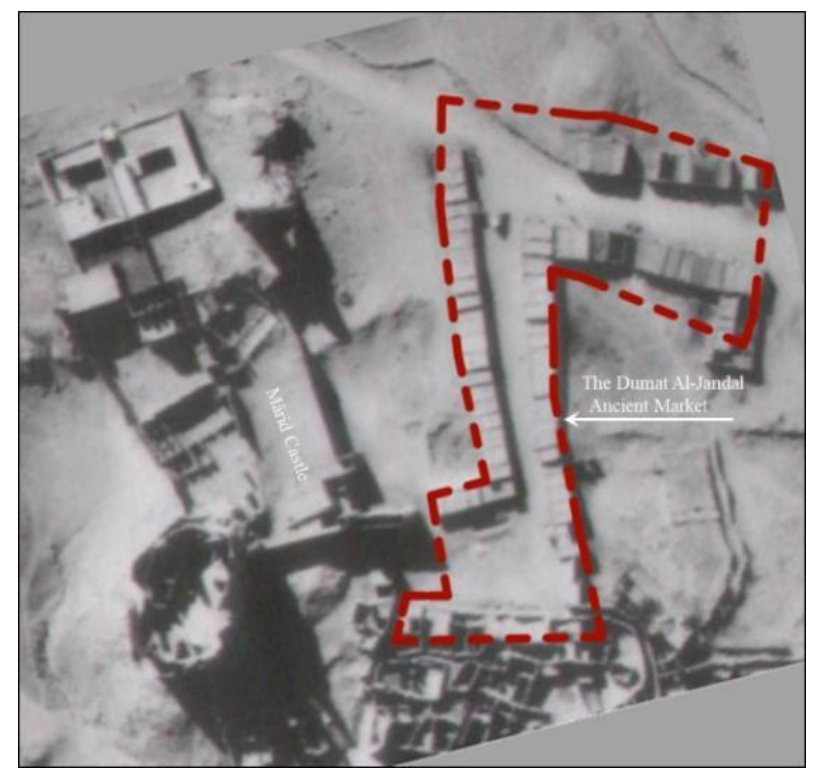

Figure 6. Aerial image showing the historic old market (Ministry of 
Interior; Municipal and Rural Affairs, 1964)

The second data collection method involved collecting documents and information from various government agencies such as Dumat Al-Jandal Municipality. This step was effective and important in the process of gathering information. In 1964, Municipal and Rural Affairs, then part of the Ministry of the Interior, took an aerial photograph that included the ancient Dumat al-Jandal market. This picture accurately shows the market's location and the approximate number of shops (Figure 6).

To determine the market's original location in relation to the modern development of the surrounding area, a modern image has been used from Google Earth (Figure 7) showing the present area where the old market was located and all the aforementioned archaeological monuments surround the site. In addition, the municipality of Dumat Al-Jandal provided a contour map of the area where the market was located. This $1 / 1000$ scale cadastral map obtained from the city municipality served as the study's main topographic data. Figure (8) depicts the contour lines of the ancient Dumat Al-Jandal market. This map provided the study's most essential and useful data, yielding rough estimates of the location and height of surrounding buildings.

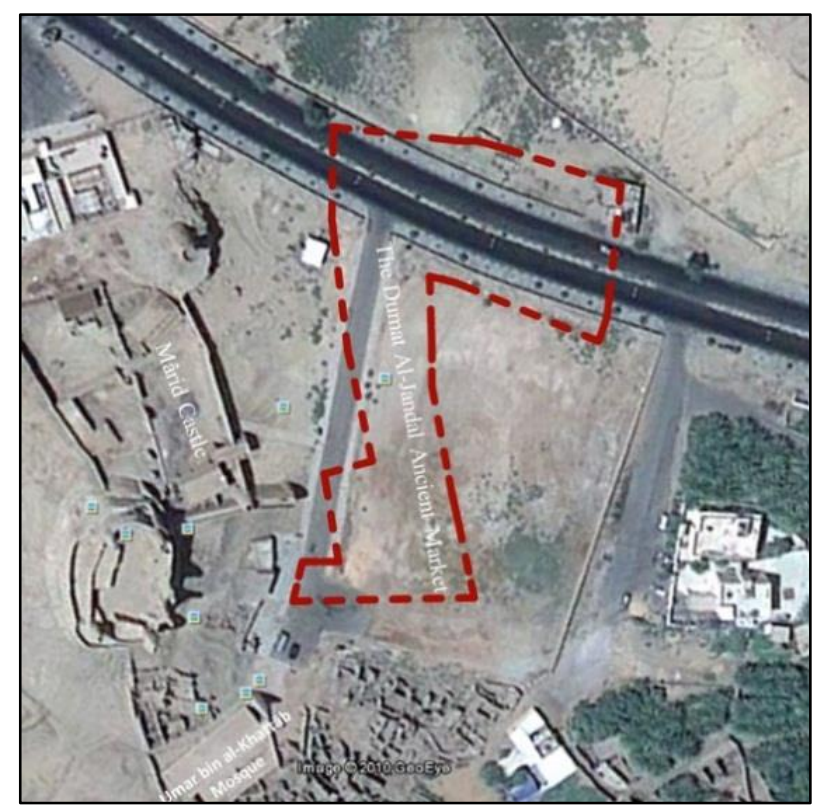

Figure 7. Image showing the present area where the historic old market will be rebuilt (Google Earth)

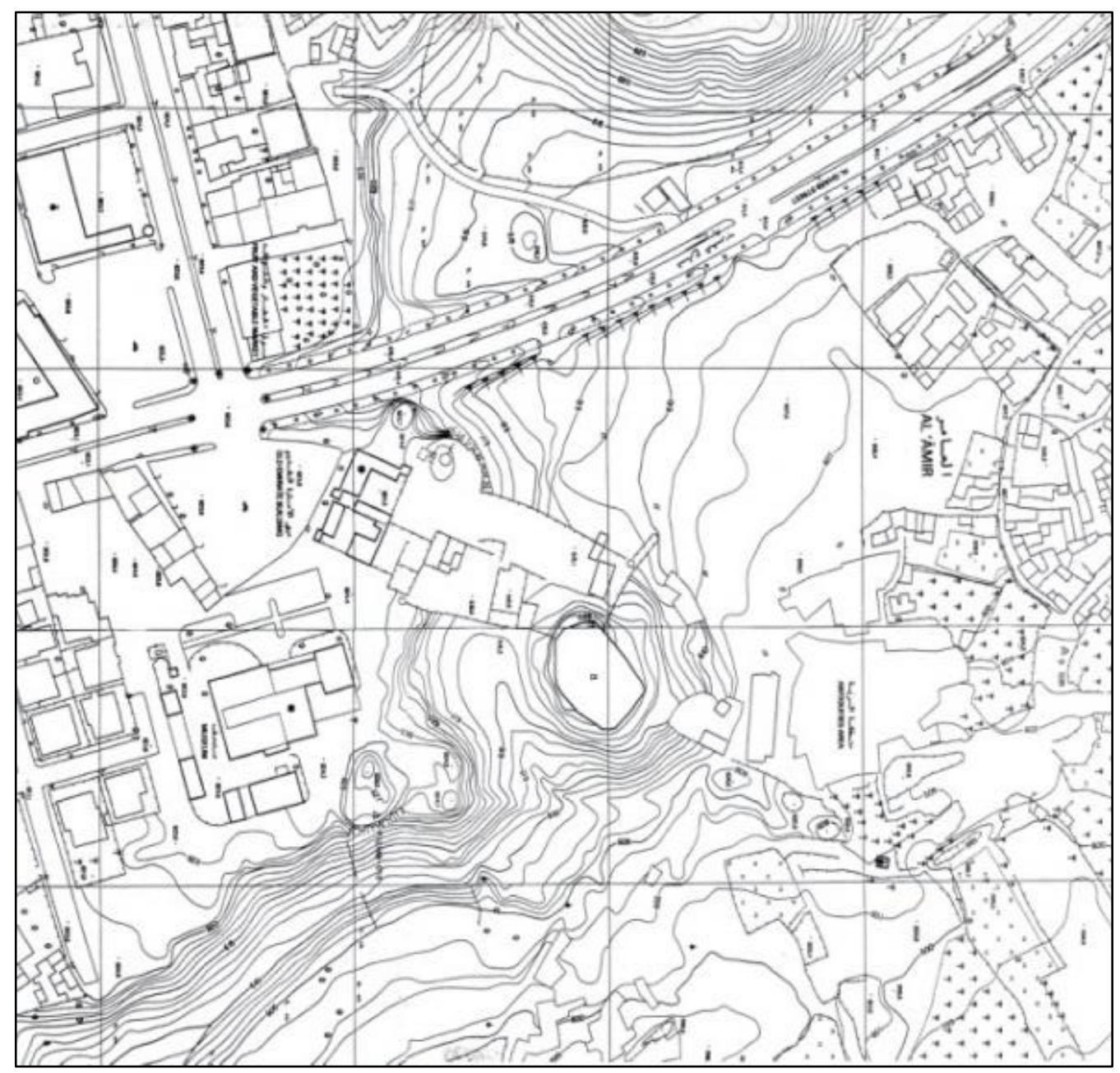

Figure 8. Map showing the current contours of the study area at 1:1000 scale (Municipality of Dumat Al-Jandal) 
Following the data collection process, the second research step involved determining the locations and numbers of shops, along with their areas, entry and exit locations, and dimensions, as well as a full visualization of the alley through the market that clarified its distributions, dimensions, and entry and exit locations through the market area.

\subsection{Architectural Process}

As stated before, this model should be sufficiently accurate for physically reconstructing the market. Accuracy here includes not only determining precise location but also accuracy with regard to the period's architectural style. The study focused on achieving high accuracy with a delicate balance between the rebuilt market and the surrounding archaeological buildings, which required precisely mapping the alley's location with respect to the current layout in addition to the precise distribution of the number of shops in the market as shown in the 1964 aerial photograph.

Thus, via comparing the ancient aerial photograph of the market with the recent satellite image obtained from Google Earth, it leaded to:

1. The original location of the old market has been precisely determined.

2. The location of a few shops in the market overlap with the area's main road, as Figure (9) shows, thus revealing the main reason for the market's destruction.

Because the original locations of a few shops were incompatible with the current location of the road, it was proposed that the orientation of these shops be aligned with the throughway. The market could be largely rebuilt in the same original location with the orientation of these shops adjusted for compatibility with the highway as shown in Figure (10). A 2-D CAD-drawn contour map was then used to determine the number, dimensions, and levels of stores in the reconstructed market and entry and exit locations, as in Figures from (10) to 12).

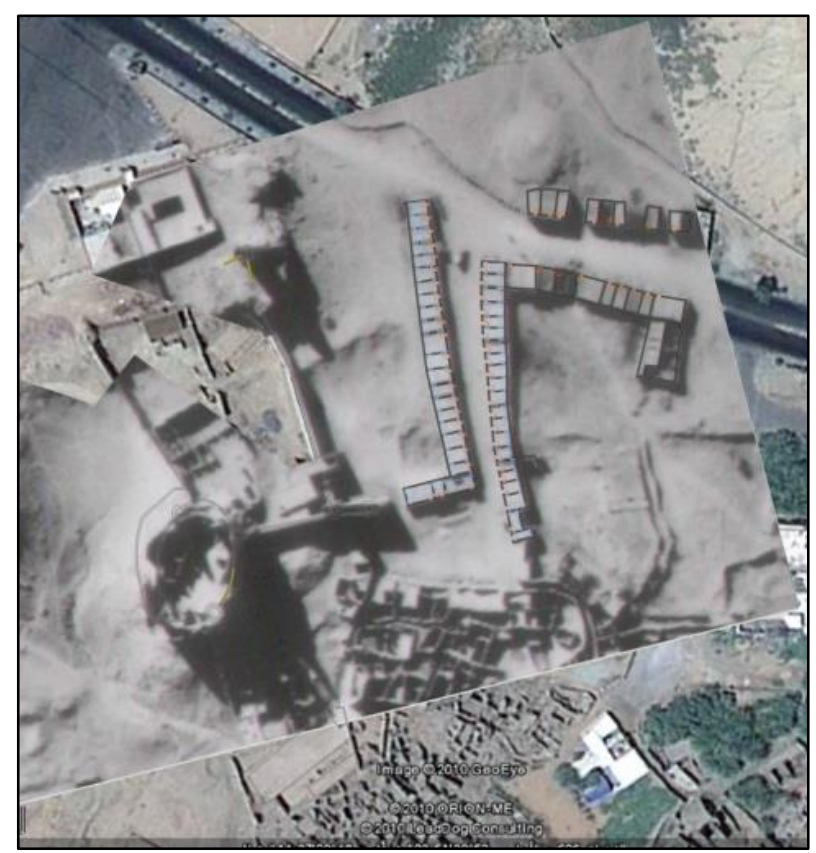

Figure 9. The original location of the Dumat Al-Jandal ancient market and a few shops overlapping with the main road

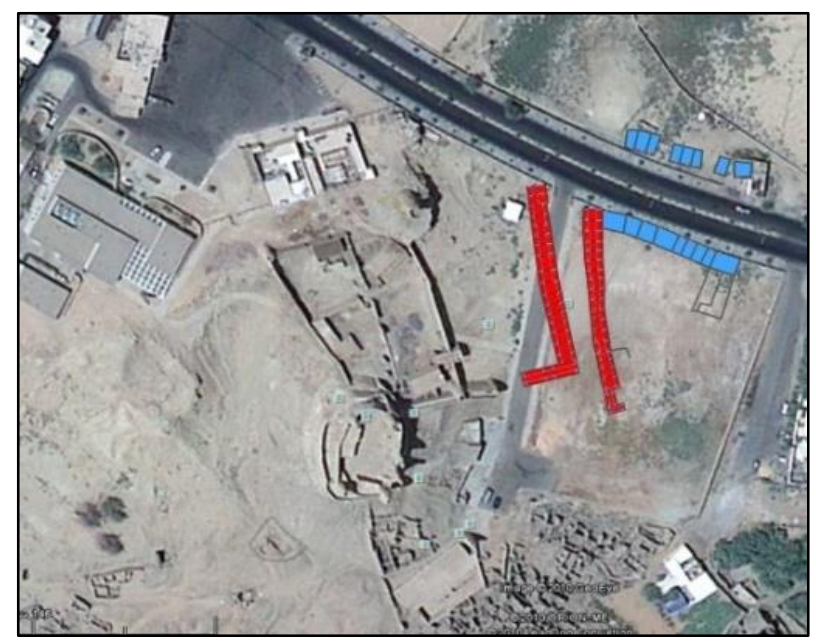

Figure 10. The original location for the reconstructed market`s shops 


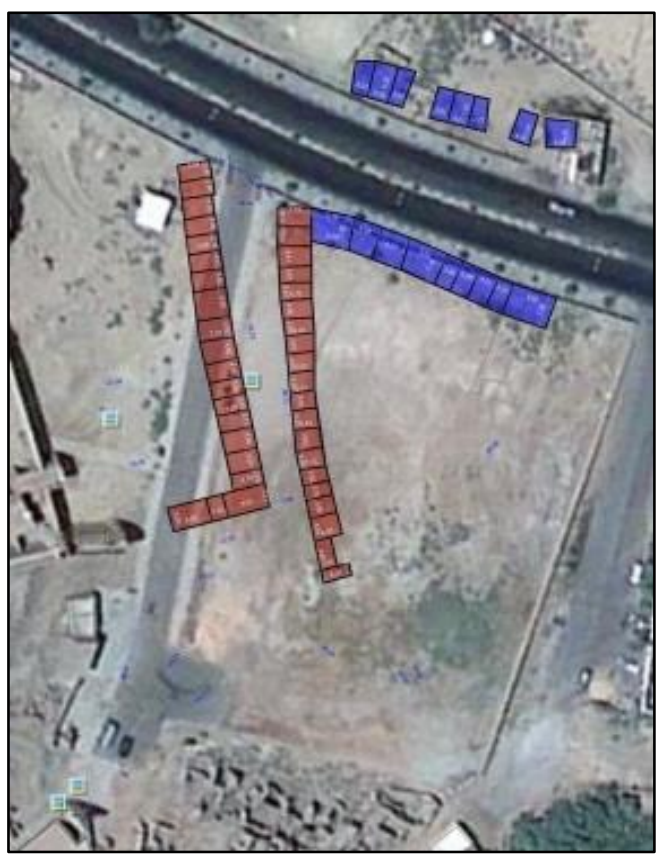

Figure 11. Numbers and dimensions of the reconstructed market`s shops

An old expansion of the market is shown at the western edge of the market where the main road is located. Figure (11) shows this expansion on both sides of the road. Because these shops in their old situation are incompatible with the current thoroughfare, the proposed visualization requires adjusting and rotating the orientation of the blue shops east of the road as shown in the above figures.

From the above figures one can see that the proposed visualization is the ancient market maintained in its original position and, moreover, the maintenance of its layout, which consists of two rows of shops (red) in the form of a major axis leading to the 'Omar bin al-Khattab mosque and the ancient archaeological district. This axis

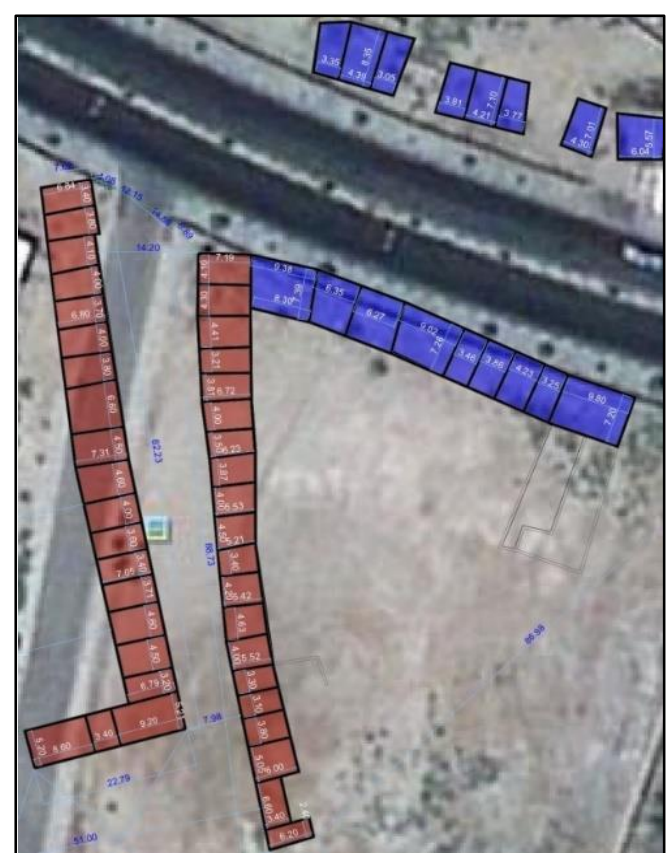

ends with a large piazza overlooked by some of the market shops.

According to this proposed visualization, the south side of the market, toward the Mârid Castle, would be approximately 88.23 meters long, and the north side would be approximately 88.73 meters long. The approximate dimensions of each shop would be 4-5 meters in width and 7-9 meters in length. In addition, the location of the surrounding market was determined by coordinating system with $(29.811118 \mathrm{~N}, 39.866209 \mathrm{E})$, $(29.811398 \mathrm{~N}, 39.866026 \mathrm{E}),(29.811912 \mathrm{~N}, 39.866608$ E), and (29.811611 N, 39.866774 E) as shown in (Figure 12). 


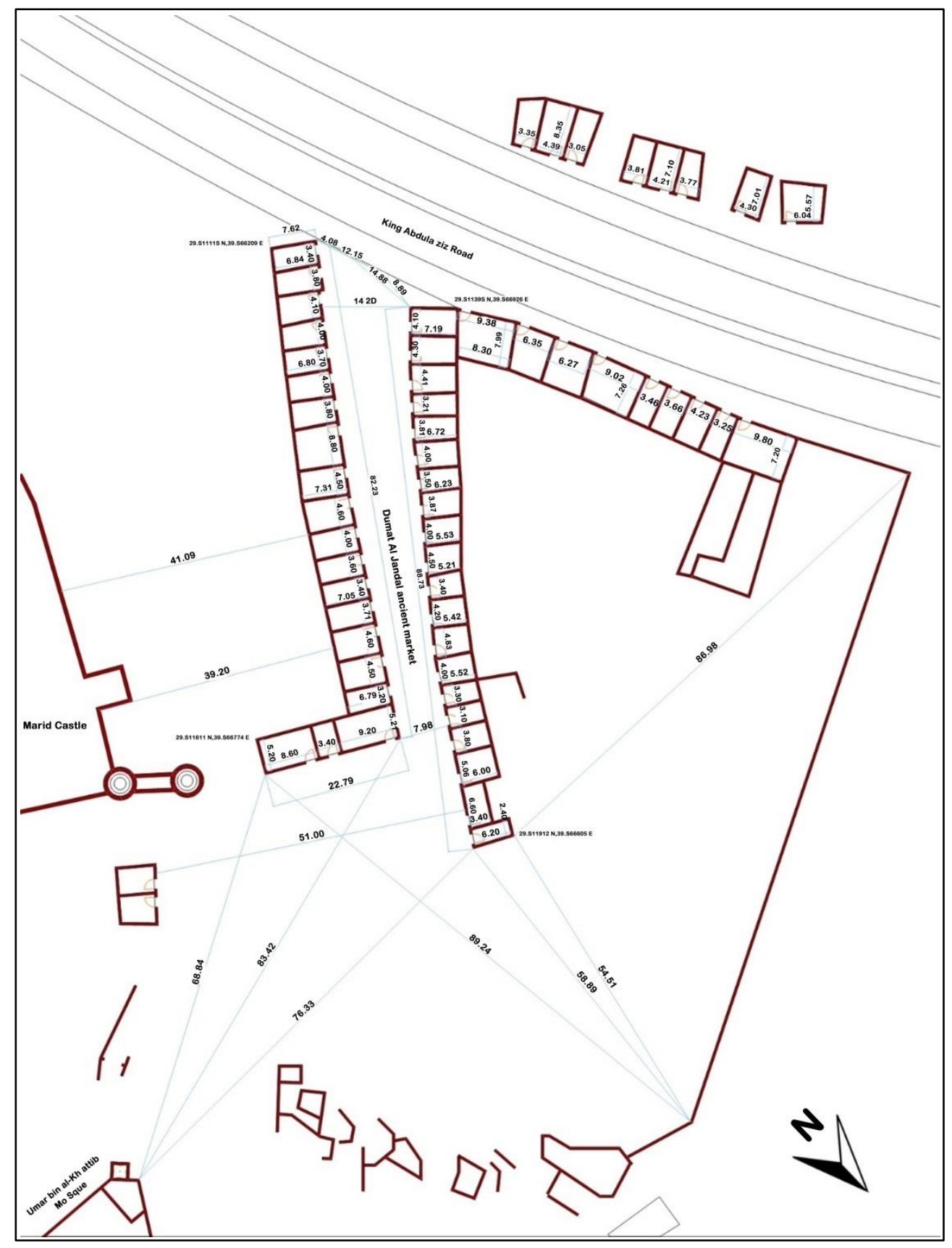

Figure 12. Site plane of Dumat Al-Jandal ancient market

\subsection{Terrestrial Photogrammetric Images}

Creating terrestrial photogrammetric images was the third step of the study. The study area included numerous architectural buildings such as Mârid Castle, 'Umar bin al-Khattâb Mosque, the Aldara archaeological quarter, and Jouf Regional Museum. Figures (13 to 16) show a collection of images of the historic buildings and sites surrounding the archaeological market location. These images provide a perception of the surrounding area of the market for extracting the buildings' 3-D information considered in the modeling phase.

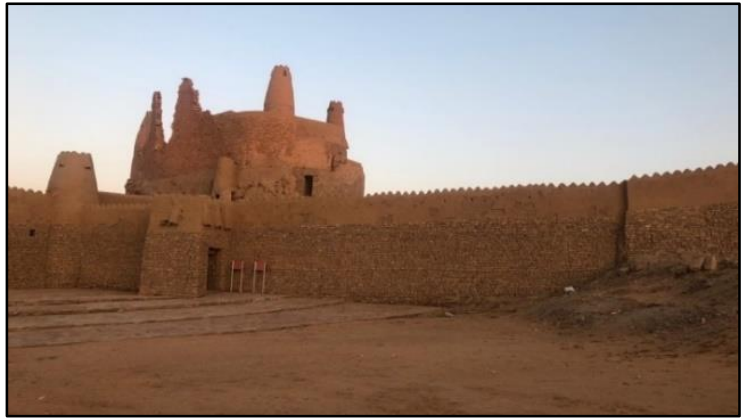

Figure 13. Real image of the western view of the Mârid Castle 


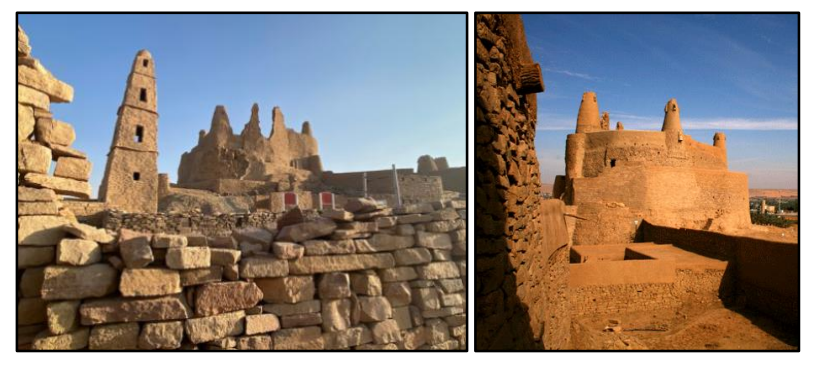

Figure 14. Another real images of the Mârid Castle
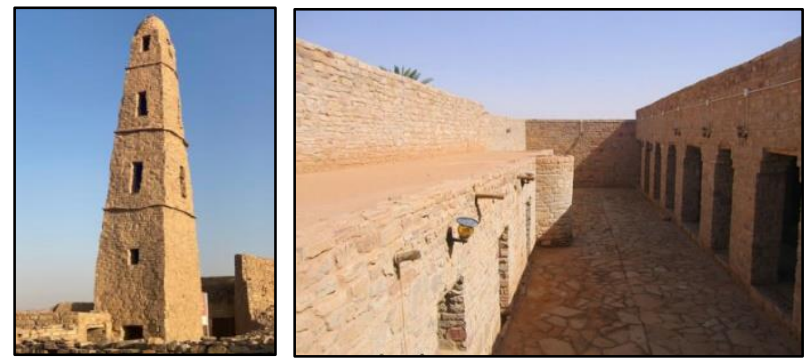

Figure 15. Real images of 'Umar bin Alkhattab Mosque

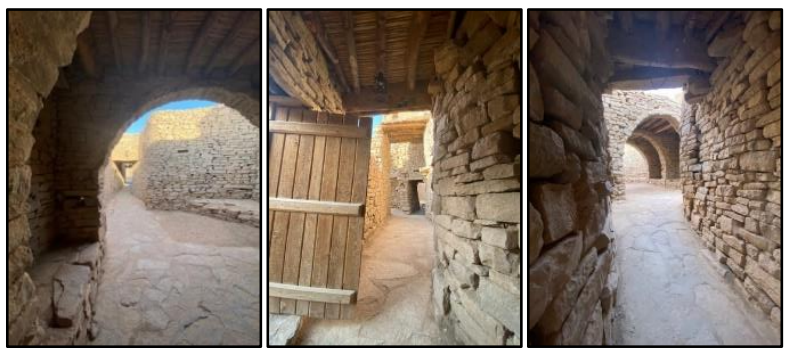

Figure 16. Real images of the Aldara archaeological quarter

\subsection{3-D Modeling and Rendering}

In the previous stage, the digital data from both aerial photographs and contour maps were combined using image processing programs and CAD programs to achieve a preliminary visualization of the number of shops and alleys' locations and modification of the positions of a few shops that were inconsistent with the area's main road. In this phase, a 3-D model of the market and related shops and the surrounding areas were made using 3-D software, after which said software and photo processing were used to render scenes (animation) and produce them to document the Dumat Al-Jandal ancient market as shown in Figures from (17) to (26).

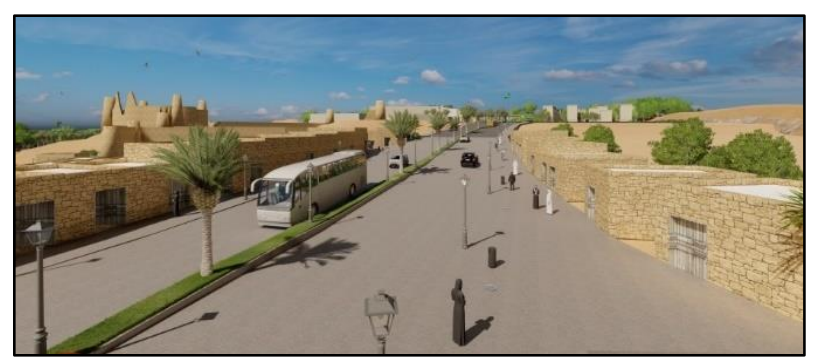

Figure 17. View to the south showing Dumat Al-Jandal ancient market and main street

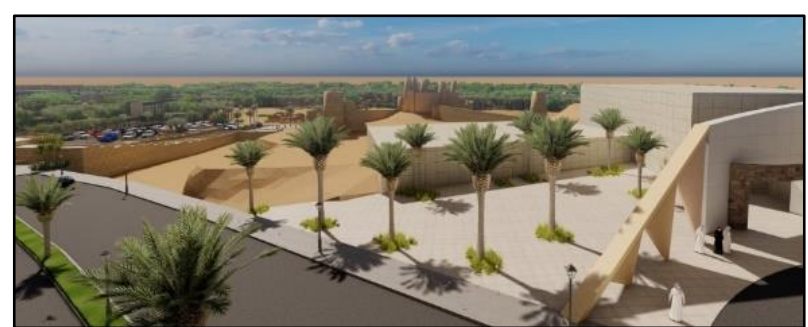

Figure 18. View to the north showing partial view of Jouf Regional Museum and heritage area

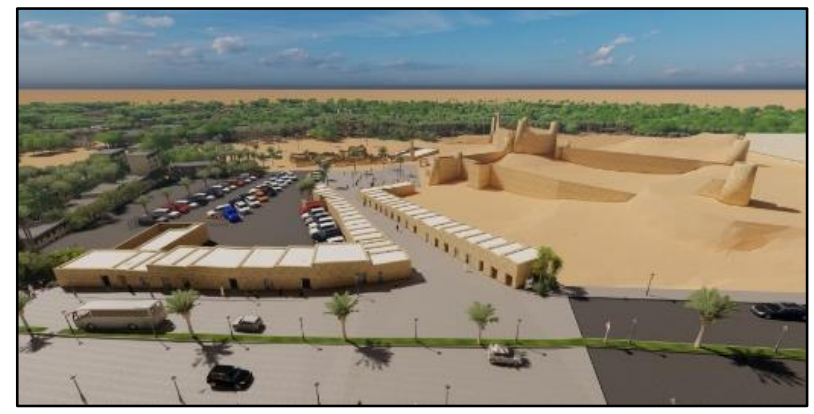

Figure 19. View to the east showing Dumat Al-Jandal ancient market with surrounding area

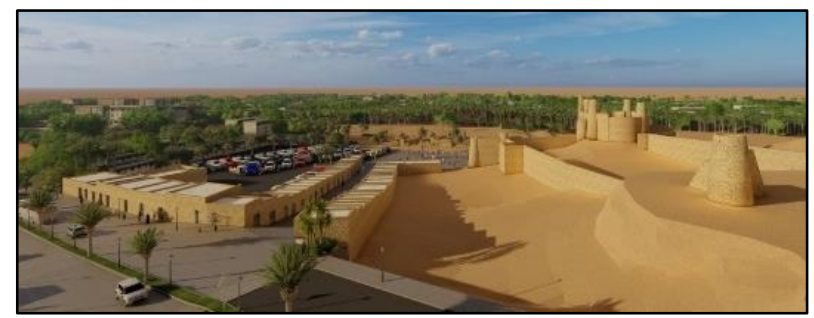

Figure 20. View to the north showing Dumat Al-Jandal ancient market with surrounding area

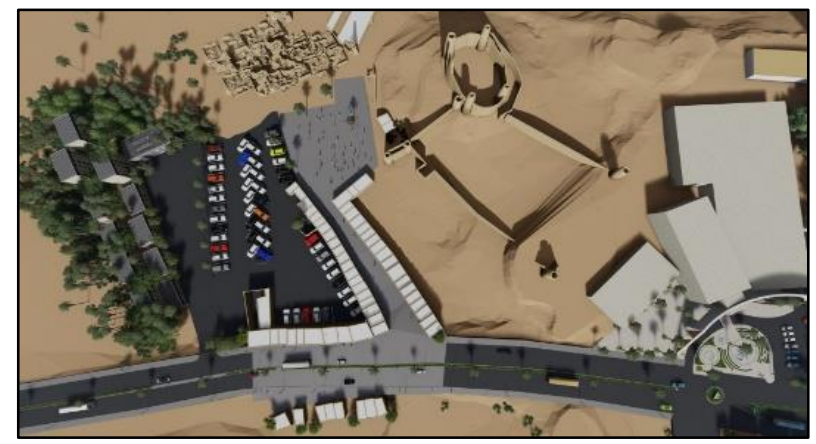

Figure 21. Site plan of ancient Dumat Al-Jandal market with surrounding area

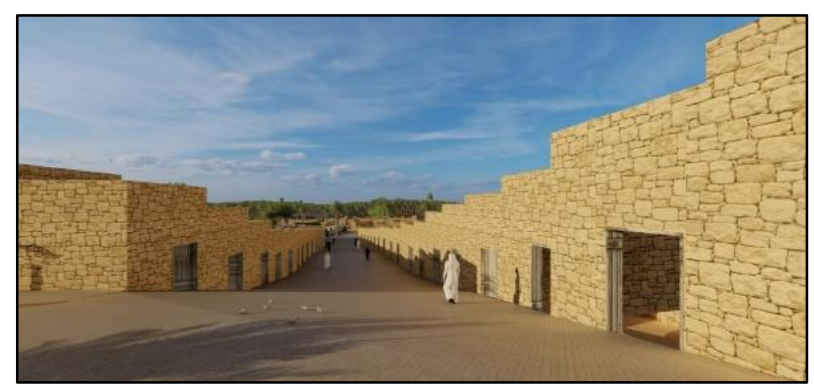

Figure 22. View of alley among two rows of shops toward the 'Omar bin al-Khattab mosque 


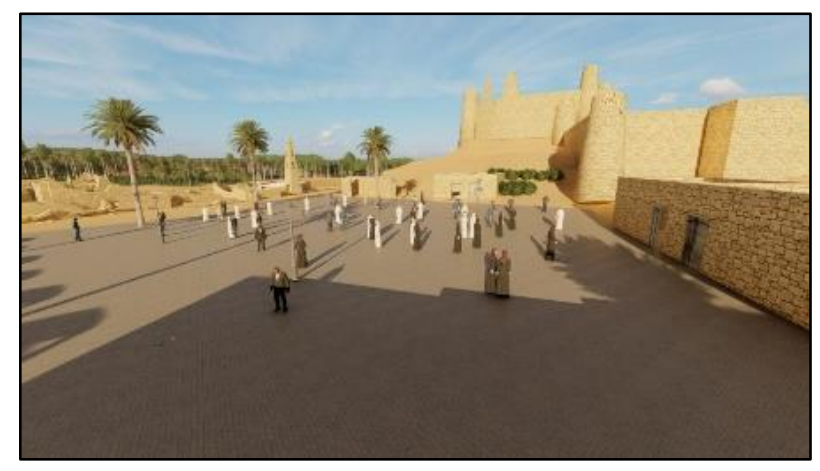

Figure 23. View showing the market piazza toward the 'Omar bin al-Khattab mosque and Mârid Castle

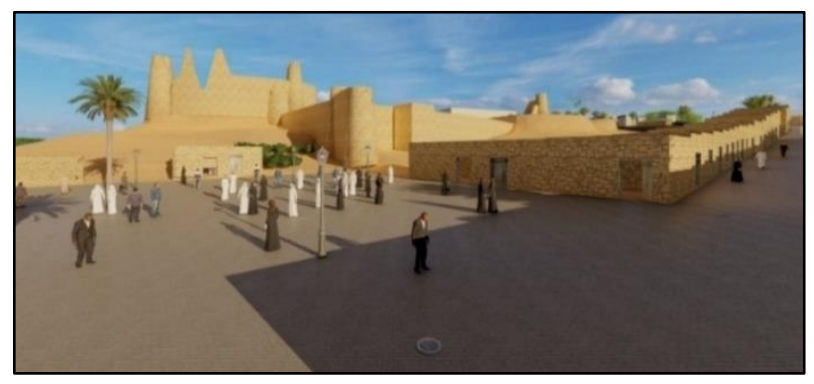

Figure 24. View showing the market piazza towards Mârid Castle and the alley

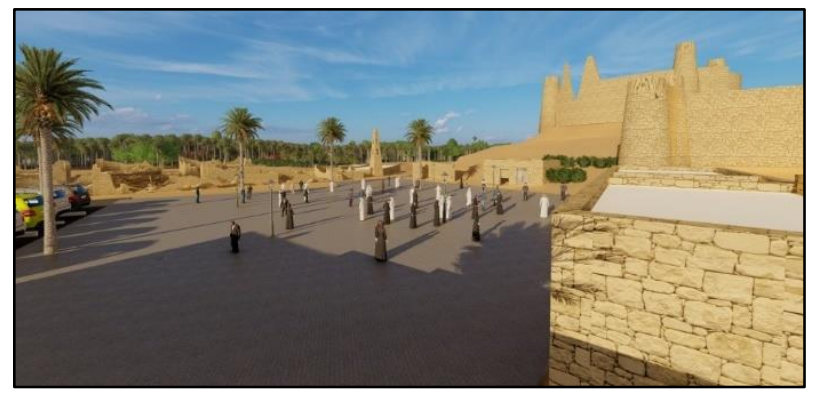

Figure 25. View showing the market piazza by the end of the alley

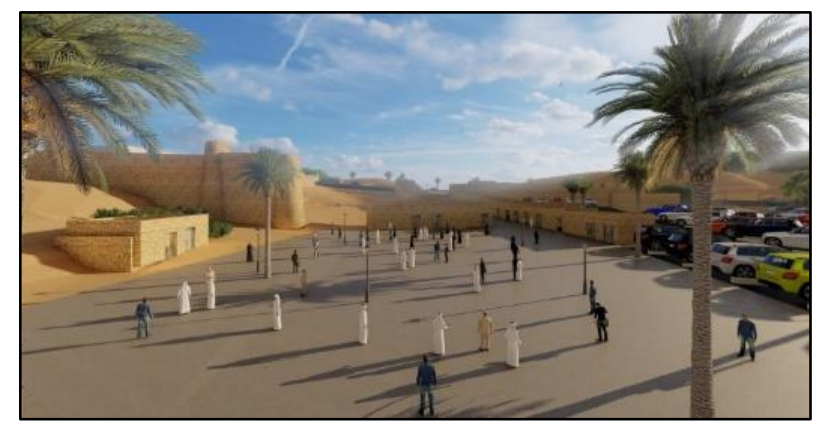

Figure 26. View to the west showing Dumat Al-Jandal ancient market from piazza

\section{Conclusions}

The historic old market in Dumat Al-Jandal is one of the most important such sites in the north of the Arabian Peninsula. This market was held annually on the first day of the month Rabiu-alawwal, the third month of the lunar calendar, and remained for about two weeks each year. The market was completely destroyed in 1974 when a portion was found to overlap with the planned King Abdul Aziz Road, a main new road in the area.

In this study the location of the historical market was able to determine through historical information, interviews, and both of old and new aerial photographs of the site. Detailed plans of the market were presented in order to benefit from its documentation in the process of reconstructing the market in the future.

The Market was located to the north-west of Mârid Castle. The distance between the market and the castle was about 40 meters. The study showed that the market consisted of two parts. The original market, which extended 83 meters from west to east, was in the form of two opposite rows. The length of the northern row was 88.73 meters and consisted of twenty shops with south-facing entrances, whereas the southern row was 82.23 meters and consisted of seventeen shops with north-facing entrances. The eastern end of the alley between these shops consisted of a small piazza with nine shops, four of which were part of the northern row, with south-facing entrances. Three other shops on the piazza had east-facing entrances and two shops had north-facing entrances.

The second part of the market was located on the western edge of the original market, perpendicular to the main alley, where the King Abdulaziz Road now passes through. This part of the market, constructed about a century ago, comprised shops on both sides of the road. There were nine shops in the eastern row, with a length of 59.20 meters, and eight shops in the western row, with a length of 52 meters. The width of all shops in the Dumat Al-Jandal market generally ranged from 3.10 to 9.8 meters, and their length generally ranged from 6.20 to 7.20 meters.

This study was showed that the construction materials used of the market were used the Al-Jandal stones, which are rough stones characterized by the Dumat Al-Jandal area. Whereas the roofs were constructed of tamarisk branches, palm leaves, and clay. In addition the doors of the shops were made of palm trunks and tamarisk branches.

Finally, modern technologies were used to help document and rebuild the market by implementing a virtual reality visualizing, site plans, and pictures of the market shown in the study. This will help those interested in urban heritage, and to provide a service to the Tourism and Municipalities Authority to use this research for reconstruction the market and enhance the urban heritage of Domat Al-Jandal.

\section{Disclosure Statement}

The Author declares that he has no conflict of interest. 


\section{REFERENCES}

[1] Al-Jasser, H. (1969). Fi shamal al-mamlaka (In the north of the kingdom). Riyadh, SA: Yamama Publishings.

[2] Almaghloth, S. (2004). The historical atlas of the biography of the Prophet Mohamed. Riyadh: Obeikan.

[3] Antonios, K., \& Loumos, G. (2019). Using different ways of $3 \mathrm{D}$ reconstruction of historical cities for gaming purposes: The case study of Nafplio. Heritage, 2, 1799-1811. DOI: $10.3390 /$ heritage 2030110

[4] Charloux, G., \& Loreto, R. (2014). Dûmat al-Jandal. 2800 years of history in the kingdom. In R. L. Guillaume Charloux, Ed., Dûmat al-Jandal. 2800 years of history in the kingdom of Saudi Arabia (p. 70). Riyadh, SA: Saudi Commission for Tourism and Antiquities-EADS Airbus Group

[5] Ghabban, A., \& Weber, S. (2010). Introduction. In A. Ghabban, A. Ibrahim, \& B. Salvini, Roads of Arabia: Archaeology and History of the Kingdom of Saudi Arabia (pp. 18-24). Washington, DC: Smithsonian Institution.

[6] Miodrag Ralevic , Tatjana Mrdjenovic , Džemila Beganović ,

Esad Muminović (2019). Tracing Path: From Conserved/ Museum towards Vivid City- Role of Urban Design. Civil Engineering and Architecture, 7(6), 286 - 295. DOI: 10.13189/cea.2019.070603.

[7] Yaman Sokienah (2020). Aspects of Sustainability in the Design Elements of Traditional Jordanian Houses. Civil Engineering and Architecture, 8(6), 1194 - 1201. DOI: 10.13189/cea.2020.080604.

[8] Luhmann, T., \& Tecklenburg, W. (2004). 3-D object reconstruction from multiple-station panorama imagery. International Archives of the Photogrammetry, Remote Sensing and Spatial Information Sciences, 34(5), 39-46.

[9] Horošavin, В. (2012). Digital 3D technology and cultural heritage. Преглед НЦД 21, 25-33.

[10] Yastikli, N. (2007). Documentation of cultural heritage using digital photogrammetry and laser scanning. Journal of Cultural Heritage, 8(4), 423-427.

[11] Koeva, M. N. (2015). 3D modelling in architectural photogrammetry (Master's thesis). Sofia, Bulgaria: UACG.

[12] Krimly, R. (2019, July 17). Saudi Arabia commits \$25mn to UNESCO for preserving heritage. Saudi Gazette. Retrieved from http://saudigazette.com.sa/article/572158 